\title{
Comparison of energy efficiency of vehicles powered by different fuels
}

\begin{abstract}
The comparison of operating fuel consumption in a selected certification test is the most popular method of assessing energy efficiency of vehicles. Operating conditions are defined with the use of a velocity profile, usually for only two categories: urban and extra urban driving. Problems arising from such a practice are discussed with the use of the analysis of operating fuel consumption calculated for selected traffic conditions in Gdansk and in its suburbs for vehicles with diesel and gasoline engines. The paper presents a new method of comparing energy efficiency of vehicles powered by different fuels, which allows to perform the analysis on the basis of one drive in a regular city traffic when basic parameters of the engine and the vehicle are recorded.
\end{abstract}

Key words: energy efficiency of vehicle, operating fuel consumption, vehicle operating conditions

\section{Porównanie efektywności energetycznej pojazdów samochodowych zasilanych różnymi paliwami}

\begin{abstract}
Najpopularniejsza metoda oceny efektywności energetycznej pojazdów samochodowych polega na porównywaniu przebiegowego zużycia paliwa osiagniętego $w$ warunkach wybranego testu homologacyjnego. Warunki eksploatacji, zdefiniowane za pomoca przebiegów prędkości w czasie, dotycza najczęściej tylko dwóch kategorii: jazdy miejskiej $i$ pozamiejskiej. Problemy wynikajace z takiego sposobu postępowania omówiono na przykładzie analizy przebiegowego zużycia paliwa w wybranych warunkach ruchu na terenie Gdańska i okolic dla pojazdów z silnikami ZS i ZI. W artykule przedstawiono nowa metodę porównywania efektywności energetycznej pojazdów zasilanych różnymi paliwami, która umożliwia wykonanie analizy na podstawie jednego przejazdu w warunkach regularnego ruchu miejskiego z rejestracja podstawowych parametrów pracy silnika i pojazdu.
\end{abstract}

Słowa kluczowe: efektywność energetyczna pojazdu samochodowego, przebiegowe zużycie paliwa, warunki eksploatacji pojazdu

\section{Introduction}

Increasing requirements for reducing emissions of toxic compounds and carbon dioxide into the atmosphere and consequently also the energy consumption by vehicles result in growing interest in methods allowing to evaluate and compare energy efficiency of vehicles $[1,2,3,10,12$, $13,14,16]$. The most popular method of assessing energy efficiency of cars and trucks is determining operating fuel consumption or carbon dioxide emissions in the conditions of a selected certification test. Such an analysis is typically performed in a laboratory with a chassis dynamometer and with the use of standardized equipment and procedures. The legitimacy of such a procedure is determined by the need to ensure reproducible testing conditions. The European test NEDC consists of two parts: the urban one UDC (Urban Driving Cycle) and the extra urban one EUDC (Extra Urban Driving Cycle). It is assumed that those tests reproduce typical traffic conditions in the city or outside the city, which have been identified by testing the actual traffic. Although the NEDC velocity profile was developed in the 60 's, it is still used by car manufacturers as the standard operating conditions encountered on European roads. The UDC test is used to determine operating fuel consumption during city driving, and EUDC test is used to determine the consumption for driving outside the city $[2,16]$. However, it needs to be noted that the results of such tests may not be representative for today's traffic conditions and the observed differences in operating fuel consumption reach large values $[2,7,8$,

\section{Wprowadzenie}

Zwiększające się wymagania w zakresie ograniczenia emisji związków toksycznych i dwutlenku węgla do atmosfery, a w następstwie również zużycia energii przez pojazdy samochodowe intensyfikują zainteresowanie metodami pozwalającymi oceniać i porównywać efektywność energetyczną pojazdów samochodowych [1, 2, 3, 10, 12, 13, 14, 16]. Najpopularniejszą metodą oceny efektywności energetycznej samochodów osobowych i dostawczych jest określenie przebiegowego zużycia paliwa lub emisji dwutlenku węgla w warunkach wybranego homologacyjnego testu jezdnego. Badanie takie wykonywane jest w laboratorium $\mathrm{z}$ hamownią podwoziową z użyciem znormalizowanych urządzeń i procedur badawczych [3, 13]. Zasadność takiego postępowania uwarunkowana jest koniecznością zapewnienia powtarzalnych warunków badań. Europejski test jezdny NEDC składa się z dwóch części: miejskiej UDC (Urban Driving Cycle) oraz pozamiejskiej EUDC (Extra Urban Driving Cycle). Powyższe testy mają w założeniach odwzorowywać typowe warunki ruchu pojazdów w mieście lub poza miastem, które rozpoznano w drodze badań rzeczywistego ruchu drogowego. Mimo że przebieg prędkości w czasie dla testu NEDC opracowano w latach 60 ., to nadal jest on przez producentów samochodów wykorzystywany jako wzorzec warunków eksploatacji spotykanych na europejskich drogach. Test UDC służy do wyznaczenia przebiegowego zużycia paliwa podczas jazdy w mieście, a test EUDC podczas jazdy poza miastem $[2,16]$. Dla współczesnych warunków ruchu wyniki 
14, 16]. The results of certification tests are also the most popular method of assessing energy efficiency of vehicles (which consists in comparing operating fuel consumption of tested vehicles). Problems arising from such a procedure are discussed by way of an analysis of operating fuel consumption calculated for selected traffic conditions in the city of Gdansk and in its suburbs. These traffic conditions were recorded in regular traffic and then used in a simulation study. A computer simulation allows for the use of the same velocity profile for the tested vehicles. The simulation results have been calculated for two configurations of the powertrain, i.e. a CI engine and a SI engine. The data obtained from the simulation were subsequently compared with the results of certification tests provided by the vehicle manufacturer.

\section{Model of the vehicle propulsion system}

The simulation model of the vehicle powertrain system (Fig. 1) used in the present paper has been developed at the Mechanical Engineering Faculty of Gdansk University of Technology $[4,5,11]$. This model was created using the Bond Graph method (BG) and the State Equations (SE) [4, 5], which allows to model elements of different physical nature. This is very important in the analysis of energy systems of complex and diverse physical nature, as is the case with vehicles with a classic or hybrid powertrain.

The first element of the vehicle powertrain system (Fig. 1) is the fuel tank $\mathbf{Z P}$ from which the fuel mass flow rate $\mathrm{G}_{\mathrm{e}}$ with a calorific value $\mathrm{W}_{\mathrm{d}}$ is supplied to the engine $\mathbf{S}$. In the given powertrain system, the engine model $\mathbf{S}$ is linked to the model of motion resistance by manual transmission $\mathbf{P W}$, main transmission PG and the wheels K. Dissipative forces result from rolling resistance $R_{t}$, air drag $R_{p}$ and braking resistance $R_{H}$. Two energy accumulators have been selected i.e. the kinetic energy in the form of reduced mass $\mathrm{m}_{\mathrm{zj}}$ and the potential energy in the form of height $\mathrm{H}$, at which the vehicle was located. The introduction of energy-modulated transmitter PEW resulted from the adoption of different axes for forces parallel to the road and gravitational forces which determine the potential energy. The internal combustion engine in the vehicle powertrain model was treated as a "black box", the fuel mass flow rate is determined by the approximation of takich testów mogą jednak nie być reprezentatywne, a obserwowane różnice w przebiegowym zużyciu paliwa osiągają duże wartości $[2,7,8,14,16]$. Wyniki badań homologacyjnych stanowią jednocześnie podstawową metodę oceny efektywności energetycznej pojazdów samochodowych, która polega na porównywaniu uzyskanego w teście przebiegowego zużycia paliwa. Problemy wynikające z takiego sposobu postępowania omówiono na przykładzie analizy przebiegowego zużycia paliwa w wybranych warunkach ruchu pojazdów na terenie Gdańska i terenach podmiejskich. Przedstawiono wyniki badań symulacyjnych wybranego pojazdu dla dwóch konfiguracji układu napędowego: wyposażonego w silnik ZI oraz ZS. Badania przeprowadzono dla warunków ruchu zarejestrowanych w regularnym ruchu. Wykorzystanie metody symulacji komputerowej daje możliwość wielokrotnego użycia tego samego przebiegu prędkości podczas badań różnych pojazdów. W warunkach drogowych odtworzenie dokładnie takiego samego przejazdu nie jest możliwe. Uzyskane wyniki porównano z rezultatami testów homologacyjnych prezentowanymi przez producenta pojazdu.

\section{Model układu napędowego pojazdu}

W badaniach symulacyjnych wykorzystano model układu napędowego pojazdu (rys. 1) opracowany na Wydziale Mechanicznym Politechniki Gdańskiej [4, 5, 11]. Model ten wykonano z użyciem metody Grafów Wiązań (GW) i Równań Stanu (RS) [4, 5], która daje możliwość modelowania elementów o różnej naturze fizycznej. Jest to bardzo istotne przy analizie energetycznej systemów o złożonej i zróżnicowanej strukturze energetycznej, np. w odniesieniu do pojazdów samochodowych z klasycznym lub hybrydowym układem napędowym.

Pierwszym elementem modelu układu napędowego pojazdu (rys. 1) jest zbiornik paliwa ZPP, z którego strumień masy paliwa $\mathrm{G}_{\mathrm{e}}$ o wartości opałowej $\mathrm{W}_{\mathrm{d}}$ jest dostarczany do silnika S. W przyjętym układzie napędowym powiązanie modelu silnika $\mathbf{S}$ oraz modelu oporów ruchu następuje przez przekładnię wybieralną PW, przekładnię główną PG oraz koła jezdne K. Siły dysypacyjne związane są z oporami toczenia $\mathrm{R}_{\mathrm{t}}$ oporami powietrza $\mathrm{R}_{\mathrm{p}}$ oraz oporami hamowa-

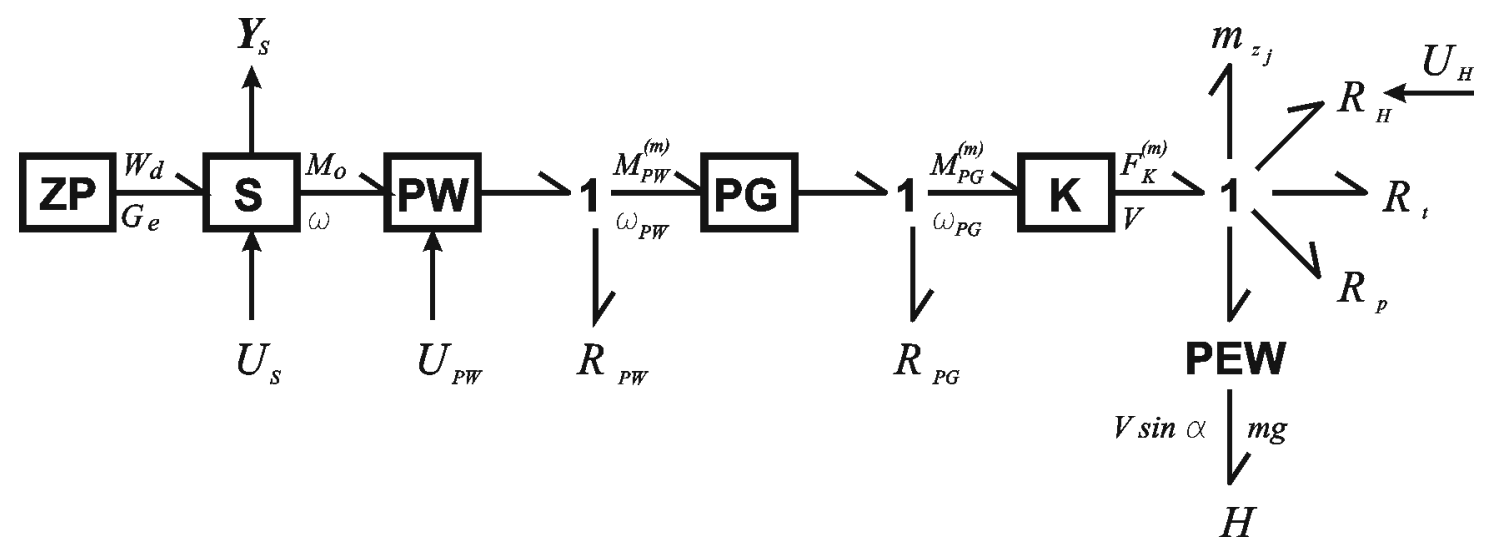

Fig. 1. Vehicle's propulsion system model in BG form [4]

Rys. 1. Model ukladu napędowego pojazdu w formie GW [4] 
the quantities measured in steady states. However, the use of static characteristics for modeling the fuel mass flow rate in transient states can lead to some errors.

In the present study the model of the vehicle Fiat Stilo for two powertrain configurations (equipped with a compression ignition engine (CI) and a spark ignition engine (SI)) has been used. Selected parameters of the modeled vehicle have been shown in Tab. 1. According to the data provided by the manufacturer of the vehicle, Fiat Stilo with a diesel nia $\mathrm{R}_{\mathrm{H}}$. Wyodrębniono dwa akumulatory energii związane z siłami zachowawczymi: energii kinetycznej w postaci zredukowanej masy $\mathrm{m}_{\mathrm{zj}}$ oraz energii potencjalnej $\mathrm{w}$ postaci wysokości H, na której znajduje się pojazd. Wprowadzenie modulowanego przetwornika energii PEW wynikało z przyjęcia różnych osi dla sił równoległych do drogi i sił grawitacji określających energię potencjalną. Silnik spalinowy w modelu układu napędowego pojazdu potraktowano jak „czarną skrzynkę”, masowy strumień paliwa określany

Table 1. Selected parameters of the vehicle used in tests

Tabela 1. Wybrane parametry pojazdu wykorzystane $w$ badaniach

\begin{tabular}{|c|c|c|c|}
\hline \multirow{2}{*}{$\begin{array}{l}\text { Name of parameter/ } \\
\text { nazwa parametru }\end{array}$} & & \multicolumn{2}{|c|}{ Value of parameter/wartość parametru } \\
\hline & & Fiat Stilo 1,9 JTD (CI/ZS) & Fiat Stilo 1,6 (SI/ZI) \\
\hline Fuel type/rodzaj paliwa & & diesel $(\mathrm{ON})$ & gasoline $(\mathrm{ET})$ \\
\hline Fuel density/gęstość paliwa & {$\left[\mathrm{kg} / \mathrm{dm}^{3}\right]$} & 0.835 & 0.705 \\
\hline Vehicle's mass/masa samochodu & {$[\mathrm{kg}]$} & 1375 & 1245 \\
\hline Year of production/rok produkcji & & 2002 & 2002 \\
\hline Emission standard/standard emisji spalin & & Euro 3 & Euro 3 \\
\hline Engine's displacement/objętość skokowa silnika & {$\left[\mathrm{dm}^{3}\right]$} & 1910 & 1581 \\
\hline Engine's maximum power/moc maksymalna silnika & {$[\mathrm{kW}]$} & 78 & 76 \\
\hline Engine's maximum torque/maksymalny moment obrotowy silnika & {$[\mathrm{N} \cdot \mathrm{m}]$} & 270 & 146 \\
\hline Final drive ratio/przełożenie przekładni głównej & {$[-]$} & 2.85 & 3.73 \\
\hline $1^{\text {st }}$ gear ratio/przełożenie na 1 . biegu & {$[-]$} & 3.91 & 3.91 \\
\hline $5^{\text {th }}$ gear ratio/przetożenie na 5. biegu & {$[-]$} & 0.77 & 0.9 \\
\hline
\end{tabular}

engine weighs $130 \mathrm{~kg}$ more than the same version of Fiat Stilo with a gasoline engine. This situation is typical for this class of vehicles, because the diesel engine generally has a larger engine displacement and additional equipment such as the turbocharger, the supply-air cooling system, soundproofing materials, engine and fuel filters of a higher weight. The model of the powertain system of the vehicle in question uses the universal characteristics of the specific fuel consumption obtained from the manufacturer of the engine:

$$
g_{e}=\frac{G_{e}}{\omega \cdot M_{o}}
$$

where: $G_{e}$ - fuel mass flow rate, $\omega$ - angular velocity of the crankshaft, $\mathrm{M}_{\mathrm{o}}$ - engine torque.

Figures 2 and 3 depict the characteristics of specific fuel consumption of engine powered by diesel fuel and gasoline.

\section{Comparison of operating fuel consumption for selected tests}

For the purpose of the present analysis five drives in the regular traffic in Gdansk, on a highway and outside the city have been selected. Randomly chosen vehicle was tracked by the test vehicle in order to limit any influence of the test driver's individual driving style on the test results [12]. Selected drives were considered representative of the following conditions: jest na podstawie aproksymacji wielkości mierzonych w warunkach statycznych. Wykorzystanie charakterystyk statycznych do modelowania masowego strumienia paliwa w warunkach dynamicznych może natomiast prowadzić do powstania pewnych błędów.

W pracy wykorzystano model pojazdu Fiat Stilo dla dwóch konfiguracji układu napędowego: wyposażonego w silnik o zapłonie samoczynnym (ZS) oraz zapłonie iskrowym (ZI). Wybrane parametry modelowanego pojazdu przedstawiono $\mathrm{w}$ tab. 1. Zgodnie $\mathrm{z}$ danymi dostarczonymi przez

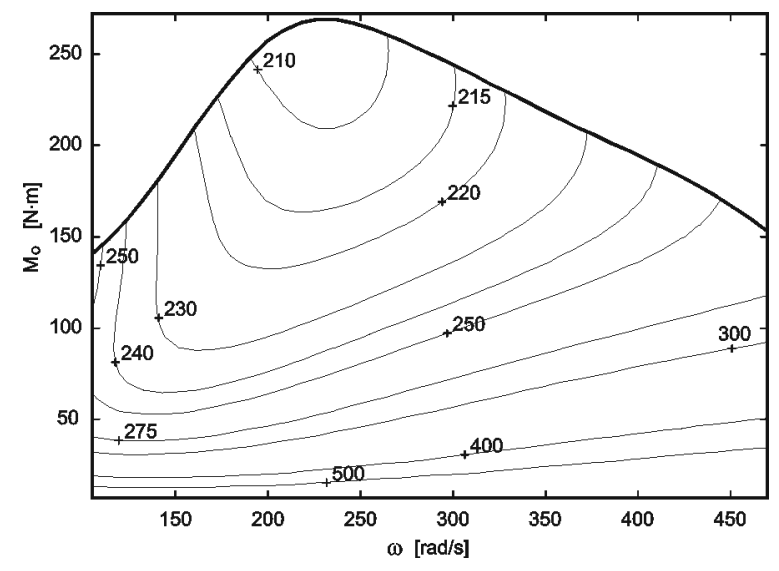

Fig. 2. Characteristics of specific fuel consumption (1) of CI engine $[\mathrm{g} /(\mathrm{kW} \cdot \mathrm{h})]$

Rys. 2. Charakterystyka jednostkowego zużycia paliwa (1) silnika ZS $[\mathrm{g} /(\mathrm{kW} \cdot \mathrm{h})]$ 


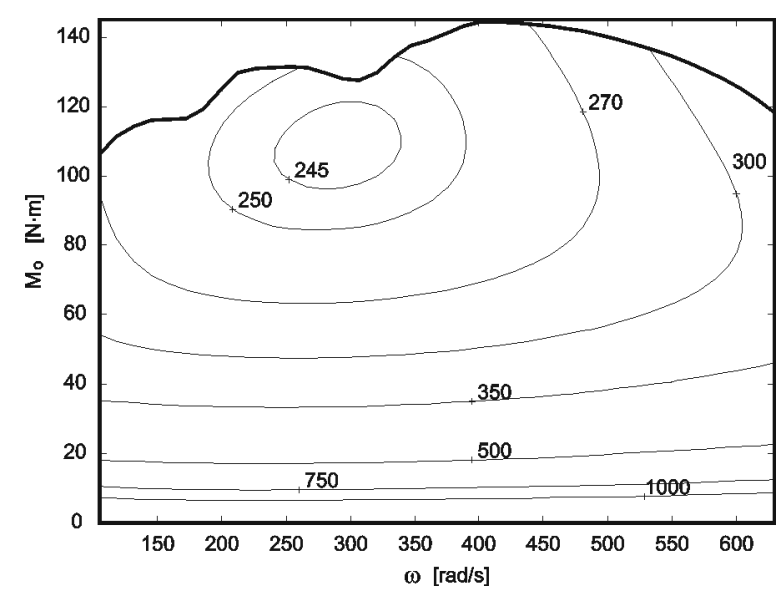

Fig. 3. Characteristics of specific fuel consumption (1) of SI engine $[\mathrm{g} /(\mathrm{kW} \cdot \mathrm{h})]$

Rys. 3. Charakterystyka jednostkowego zużycia paliwa (1) silnika ZI $[\mathrm{g} /(\mathrm{kW} \cdot \mathrm{h})]$

- driving the main thoroughfare of the city (city center) -

Fig. 4, the route for heavy traffic conditions; the reported results refer to the conditions most similar to the average ones obtained in 42 drives on weekdays, implemented in the following hourly intervals: $\{600-900 ; 900-1200$; $1200-1500 ; 1500-1800 ; 1800-2100 ; 2100-600\}$,

- driving in a traffic jam (traffic jam) - Fig. 5, the route with frequent stops forced by restrictions on movement; the drive was classified in this way, if the average speed was less than $20 \mathrm{~km} / \mathrm{h}$,- dynamic driving in the city (dynamic driving) - Fig. 6, the route with frequent stops forced by traffic lights, a dynamic driving style; driving style was classified as dynamic, if the average torque in the drive mode was greater than that set for driving the main thoroughfare of the city by at least $50 \%$,

- outside the city driving (outside the city) - Fig. 7, the route located outside the city with few stops, the drive was classified as outside the city driving, if the average speed was greater than $50 \mathrm{~km} / \mathrm{h}$,

- driving on the highway (highway) - Fig. 8; the drive was classified as driving on the highway, if the average speed was greater than $80 \mathrm{~km} / \mathrm{h}$.

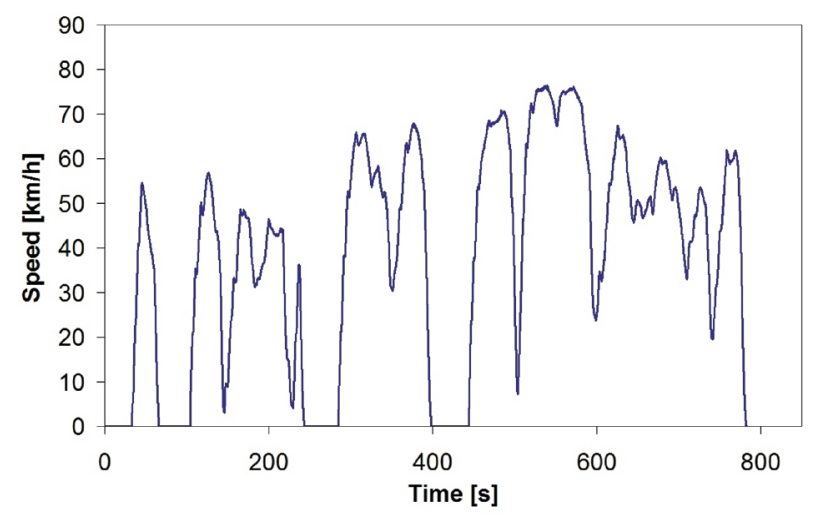

Fig. 4. Driving the main thoroughfare of the city (city center) Rys. 4. Jazda główna arteria komunikacyjna miasta (centrum miasta) producenta pojazd z silnikiem ZS ma masę o $130 \mathrm{~kg}$ większą od pojazdu z silnikiem ZI (w tej samej wersji wyposażenia). Jest to sytuacja typowa dla pojazdów tej klasy, gdyż silnik ZS z reguły ma większą objętość skokową oraz dodatkowe wyposażenie w postaci turbosprężarki, systemu chłodzenia powietrza zasilającego, materiałów wygłuszających pracę silnika i filtrów paliwa o zwiększonej masie. Do wykonania modelu układu napędowego rozważanego pojazdu wykorzystano charakterystyki ogólne jednostkowego zużycia paliwa uzyskane od producenta silników - wzór (1), gdzie: $\mathrm{G}_{\mathrm{e}}$ - strumień masy paliwa, $\omega$ - prędkość kątowa wału korbowego silnika, $\mathrm{M}_{\mathrm{o}}$ - moment obrotowy silnika.

Na rysunkach 2 i 3 przedstawiono odpowiednio charakterystyki jednostkowego zużycia paliwa silnika zasilanego olejem napędowym i benzyną.

\section{Porównywanie przebiegowego zużycia paliwa w warunkach wybranych testów}

Do analizy wybrano 5 przejazdów wykonanych w regularnym ruchu na terenie Gdańska, obwodnicy Trójmiasta i drodze podmiejskiej. W czasie wykonywania przejazdów losowo wybierano pojazd, który był „śledzony” przez pojazd testowy w celu ograniczenia wypływu indywidualnego stylu jazdy kierowcy testowego na wyniki próby [12]. Wybrane przejazdy uznano za reprezentatywne dla następujących warunków:

- jazda główną arterią komunikacyjną miasta (centrum miasta) - rys. 4, trasą o dużym natężeniu ruchu; przedstawione wyniki dotyczą warunków najbardziej zbliżonych do przeciętnych uzyskanych w 42 przejazdach w dni robocze, realizowanych w następujących przedziałach godzinowych: $\{600-900 ; 900-1200 ; 1200-1500$; $1500-1800 ; 1800-2100 ; 2100-600\}$,

- jazda w mieście w korku (korek) - rys. 5, trasą o częstych zatrzymaniach wymuszonych utrudnieniami w ruchu; przejazd klasyfikowano w ten sposób, jeżeli średnia prędkość jazdy była mniejsza niż $20 \mathrm{~km} / \mathrm{h}$,

- jazda dynamiczna w mieście (jazda dynamiczna) - rys. 6, trasą o częstych zatrzymaniach wymuszonych sygnalizacją świetlną przy dynamicznym stylu jazdy kierowcy; styl jazdy kierowcy klasyfikowano jako dynamiczny, jeżeli średni moment obrotowy silnika w fazie napędowej był większy

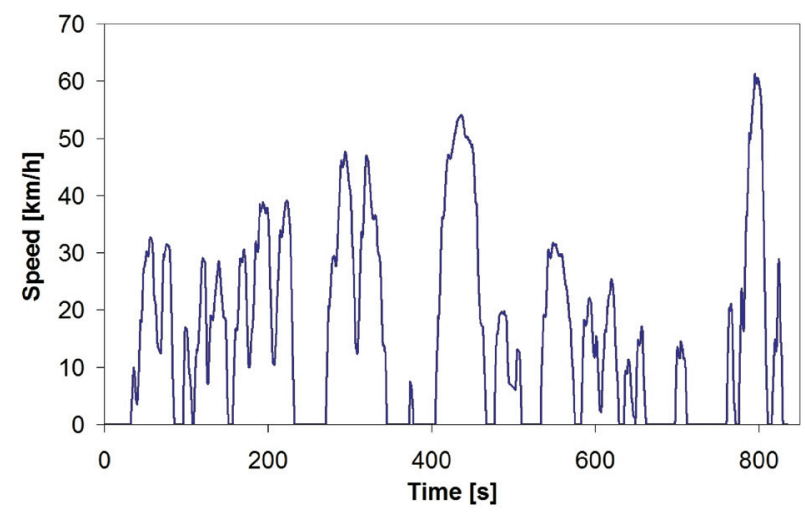

Fig. 5. Driving in a traffic jam (traffic jam) Rys. 5. Jazda w mieście w korku (korek) 


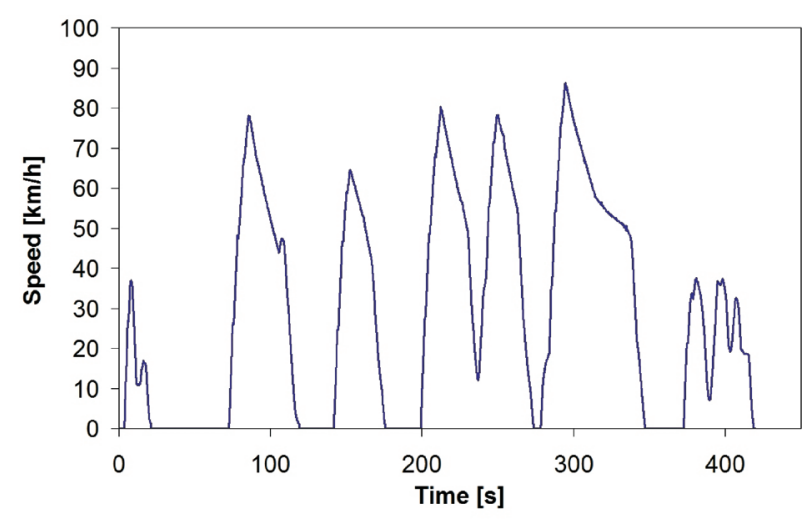

Fig. 6. Dynamic driving in the city (dynamic driving) Rys. 6. Jazda dynamiczna w mieście (jazda dynamiczna)

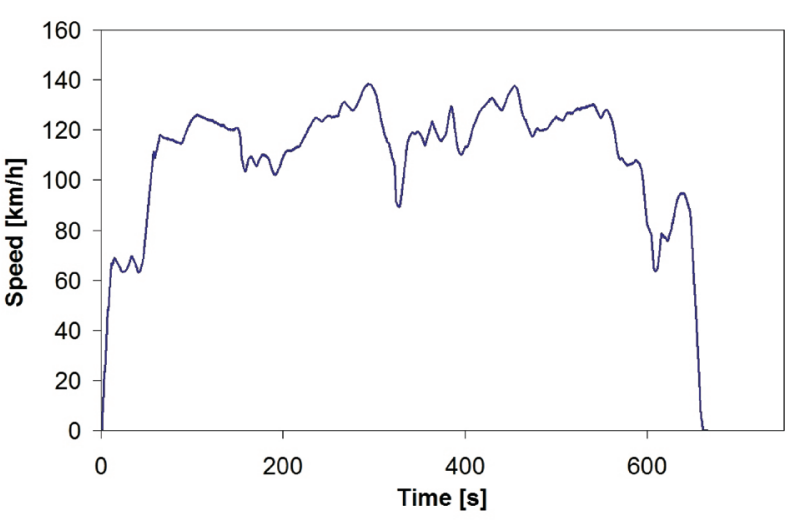

Fig. 8. Driving on the highway (highway)

Rys. 8. Jazda po drodze szybkiego ruchu (autostrada)

The analyses for the aforementioned driving conditions (Fig. $4-8$ ) have been performed with the use of the model of the vehicle powertrain system (Fig. 1). The results of these analyses are fuel mass flow rate supplied to the engine and operating fuel consumption:

$$
\mathrm{Q}=\frac{1}{\rho_{\mathrm{pal}} \cdot \mathrm{L}} \int_{0}^{\mathrm{t}_{\mathrm{c}}} \mathrm{G}_{\mathrm{e}} \mathrm{dt}
$$

where: $\rho_{\text {pal }}$ - fuel density, $t_{c}-$ measurement cycle time, $L$ - total distance travelled by the vehicle during the measurement cycle.

Figures 9 and 10 present examples of the fuel mass flow rate calculated for driving in a traffic jam, for the $\mathrm{CI}$ engine and the SI engine, respectively.

On the basis of simulation results, operating fuel consumption (expressed in cubic decimetres of diesel fuel $\left(\mathrm{Q}_{\mathrm{zS}}\right)$ or gasoline $\left.\left(\mathrm{Q}_{\mathrm{ZI}}\right)\right)$ used to travel $100 \mathrm{~km}$ has been calculated. This form of presentation of the results is preferred by vehicle users and manufacturers. Table 2 shows the results of numerical simulation and the certification test results provided by the vehicle's manufacturers together with the average driving speed in the individual tests $\left(\mathrm{V}_{\mathrm{sr}}\right)$. Due to the lower calorific value per volumetric unit of gasoline as compared to the diesel fuel (approx. 15\%) the operating energy consumption

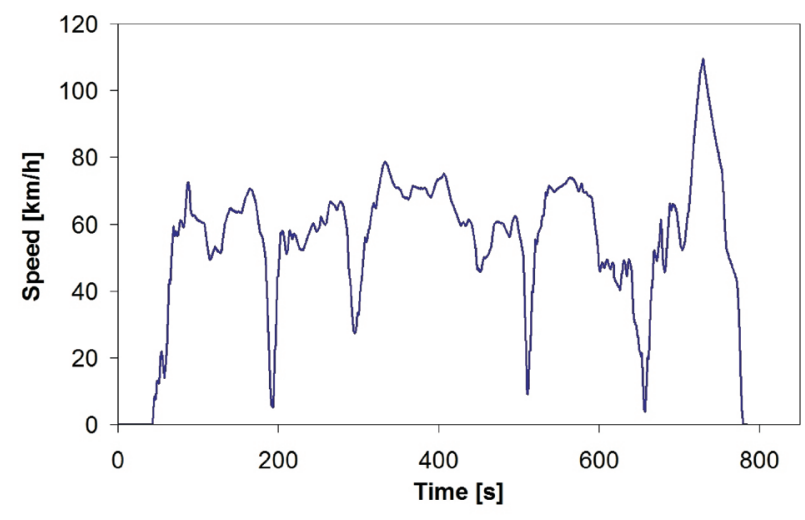

Fig. 7. Outside the city driving (outside the city)

Rys. 7. Jazda po drodze pozamiejskiej (poza miastem)

niż wyznaczony dla przeciętnych warunków jazdy główną arterią komunikacyjną miasta o co najmniej $50 \%$,

- jazda po drodze pozamiejskiej (poza miastem) - rys. 7, trasą położoną poza granicami miasta o nielicznych zatrzymaniach; przejazd klasyfikowano w ten sposób, jeżeli średnia prędkość jazdy była większa niż $50 \mathrm{~km} / \mathrm{h}$,

- jazda po drodze szybkiego ruchu (autostrada) - rys. 8; przejazd klasyfikowano w ten sposób, jeżeli średnia prędkość jazdy była większa niż $80 \mathrm{~km} / \mathrm{h}$.

Wykorzystując model układu napędowego pojazdu (rys. 1) przeprowadzono badania w warunkach opisanych powyżej przejazdów (rys. 4-8). Efektem tych badań są wyznaczone przebiegi strumienia masy paliwa dostarczanego do silnika, a następnie przebiegowego zużycia paliwa (2), gdzie: $\rho_{\text {pal }}-$ gęstość paliwa, $t_{c}-$ czas cyklu pomiarowego, $\mathrm{L}$ - całkowita droga przejechana przez pojazd w czasie cyklu pomiarowego.

Na rysunkach 9 i 10 przedstawiono przykładowe strumienie masy paliwa wyznaczone dla jazdy w mieście w korku odpowiednio dla silnika ZS i ZI.

Na podstawie uzyskanych wyników dokonano następnie obliczenia przebiegowego zużycia paliwa wyrażonego $\mathrm{w}$ decymetrach sześciennych oleju napędowego $\left(\mathrm{Q}_{\mathrm{zS}}\right)$ lub benzyny $\left(\mathrm{Q}_{\mathrm{ZI}}\right)$ zużytej do przejechania $100 \mathrm{~km}$. Taka forma prezentacji wyników jest preferowana przez użytkowników oraz producentów pojazdów. $\mathrm{W}$ tabeli 2 przedstawiono wyniki wykonanych badań symulacyjnych oraz wyniki testów homologacyjnych dostarczonych przez producenta pojazdów wraz ze średnimi prędkościami jazdy w poszczególnych testach $\left(\mathrm{V}_{\mathrm{sr}}\right)$. Ze względu na mniejszą wartość opałową jednostki objętości benzyny w stosunku do oleju napędowego (ok. 15\%) dokonano również obliczenia przebiegowego zużycia energii, które można obliczyć jako iloczyn masy paliwa i jego wartości opałowej $\left(\mathrm{m}_{\mathrm{p}} \mathrm{W}_{\mathrm{d}}\right)$. W tabeli 2 przedstawiono względną różnicę przebiegowego zużycia energii przez pojazd $z$ silnikiem ZS i ZI.

Uzyskane rezultaty (tab. 2) pozwalają stwierdzić, że pojazd z silnikiem ZI zużywa $\mathrm{w}$ każdym analizowanym przypadku więcej paliwa niż z silnikiem ZS, przy czym w homologacyjnym teście jezdnym UDC badane są silniki nierozgrzane, natomiast użyty w badaniach symulacyjnych model pozwala prowadzić obliczenia wyłącznie dla silników 


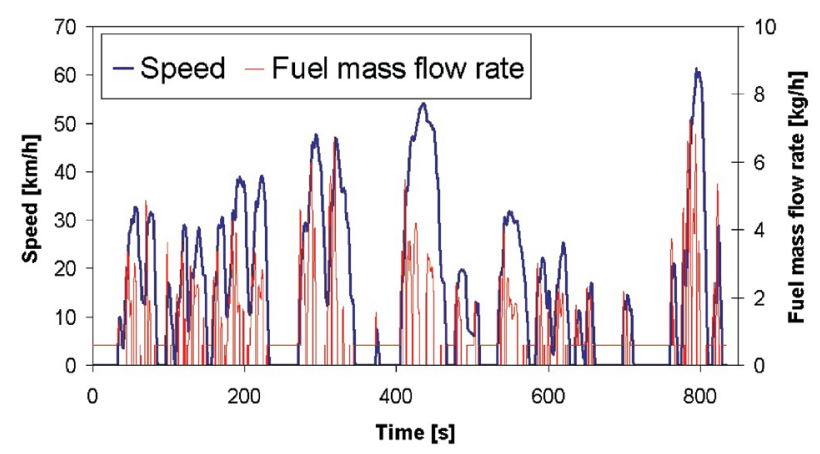

Fig. 9. Fuel mass flow rate - driving in a traffic jam (CI engine) Rys. 9. Strumień masy paliwa-jazda w mieście w korku (silnik ZS)

has also been calculated. This parameter can be calculated by multiplying the mass of fuel and its calorific value $\left(\mathrm{m}_{\mathrm{p}} \mathrm{W}_{\mathrm{d}}\right)$. The operating energy consumption is expressed in $\mathrm{MJ}$ per $100 \mathrm{~km}$ for both the diesel engine and the gasoline engine. Table 2 depicts the relative difference in operating energy consumption of the vehicle with the diesel engine and the gasoline one.

The obtained results (Tab. 2) show that the vehicle powered by gasoline consumed more fuel than the vehicle powered by diesel fuel in each analyzed case. It needs to be noted that cold engines are tested in the UDC test whereas models used in simulation tests can only be used to calculate fuel mass flow rate for warmed up engines. The difference in operating fuel consumption of vehicles powered by gasoline and those powered by diesel fuel results partly from the lower calorific value per volumetric unit of gasoline as compared to the diesel fuel, therefore, further analysis will be performed on the basis of the operating energy released from fuel. This difference varies within a relatively wide range: $(1-18) \%$, and the differences are smaller in the case of conditions that can be classified as extra urban driving.

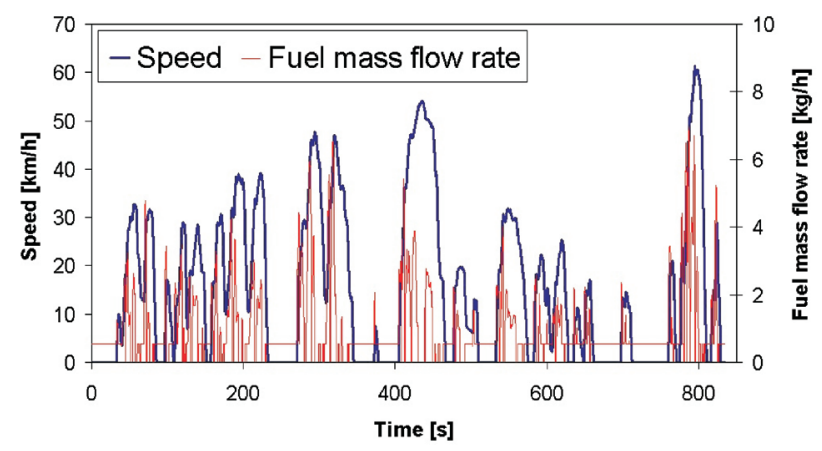

Fig. 10. Fuel mass flow rate - driving in a traffic jam (SI engine) Rys. 10. Strumień masy paliwa-jazda w mieście w korku (silnik ZI)

znajdujących się w stanie rozgrzanym. Różnica w przebiegowym zużyciu paliwa wynika w znacznym stopniu z mniejszej wartości opałowej jednostki objętości benzyny w stosunku do oleju napędowego, dlatego dalsze rozważania będą dotyczyć różnicy w przebiegowym zużyciu energii. Ta różnica zmienia się w szerokim zakresie: $(1-18) \%$, przy czym te różnice są mniejsze w warunkach, które można sklasyfikować jako jazda pozamiejska.

Na podstawie uzyskanych wyników dla warunków jazdy miejskiej można również stwierdzić, że przebiegowe zużycie paliwa zarówno dla silnika ZS, jaki i ZI zmienia się w szerokim zakresie w zależności od sposobu eksploatacji. Podobna sytuacja występuje w warunkach jazdy pozamiejskiej. Można stąd wnioskować, że porównanie efektywności energetycznej pojazdów samochodowych zasilanych różnymi paliwami powinno być wykonywane przy użyciu bardziej szczegółowej klasyfikacji warunków niż prosty podział na jazdę miejską i pozamiejską. W zależności od stylu jazdy kierowcy, istniejących utrudnień w ruchu oraz średniej prędkości jazdy różnice w przebiegowym zużyciu paliwa lub energii będą się zmieniać w szerokim zakresie.

Table 2. The results of simulation studies of the vehicle

Tabela 2. Wyniki wykonanych badań symulacyjnych pojazdu

\begin{tabular}{|c|c|c|c|c|c|c|}
\hline $\begin{array}{l}\text { Route/ } \\
\text { trasa przejazdu }\end{array}$ & $\begin{array}{c}\mathrm{V}_{\mathrm{sr}} \\
{[\mathrm{km} / \mathrm{h}]}\end{array}$ & $\begin{array}{c}\mathrm{Q}_{\mathrm{zS}} \\
{\left[\mathrm{dm}^{3} / 100 \mathrm{~km}\right]}\end{array}$ & $\begin{array}{c}\mathrm{Q}_{\mathrm{ZI}} \\
{\left[\mathrm{dm}^{3} / 100 \mathrm{~km}\right]}\end{array}$ & $\begin{array}{c}\mathrm{Q}_{\mathrm{ZI}}-\mathrm{Q}_{\mathrm{ZS}} \\
{\left[\mathrm{dm}^{3} / 100 \mathrm{~km}\right]}\end{array}$ & $\begin{array}{c}Q_{Z I}-Q_{Z S} \\
Q_{Z S} \\
{[\%]}\end{array}$ & $\frac{\left(m_{p} W_{d}\right)_{z I}-\left(m_{p} W_{d}\right)_{z S}}{\left(m_{p} W_{d}\right)_{z S}}$ \\
\hline UDC (Fiat) & 18.7 & 7.2 & 10.1 & 2.9 & 40 & 18 \\
\hline $\begin{array}{l}\text { city center/ } \\
\text { centrum miasta }\end{array}$ & 38.2 & 5.1 & 6.7 & 1.6 & 32 & 12 \\
\hline $\begin{array}{l}\text { traffic jam/ } \\
\text { korek }\end{array}$ & 15.4 & 7.7 & 9.6 & 1.9 & 25 & 6 \\
\hline $\begin{array}{l}\text { dynamic driving/ } \\
\text { jazda dynamiczna }\end{array}$ & 29.1 & 6.5 & 7.8 & 1.3 & 20 & 1 \\
\hline EUDC (Fiat) & 62.6 & 4.2 & 5.7 & 1.5 & 36 & 14 \\
\hline $\begin{array}{l}\text { outside the city/ } \\
\text { poza miastem }\end{array}$ & 54.1 & 4.3 & 6.0 & 1.7 & 39 & 17 \\
\hline $\begin{array}{l}\text { highway/ } \\
\text { autostrada }\end{array}$ & 109.8 & 6.3 & 8.5 & 2.2 & 35 & 14 \\
\hline
\end{tabular}


As it transpires from the data, operating fuel consumption for urban driving conditions varies greatly depending on the driving style for both the diesel engine and the gasoline one. The same holds for the extra urban driving conditions. Hence, it can be concluded that the comparison of energy efficiency of vehicles powered by different fuels should be performed with the use of a more detailed classification of conditions than a simple division between urban and extra urban driving. Depending on the driving style, the current traffic problems and the average speed, the differences in operating energy released from fuel or operating fuel consumption will change within a relatively wide range.

\section{Identification of vehicle operating conditions using the specific tractive energy}

Vehicle operating conditions are identified with the use of the specific tractive energy $\Phi$ that takes into account both the influence of external conditions and driver's driving style) $[11,12,15]$. The factors mentioned above affect the amount of mechanical energy transmitted to the drive wheels and they are treated as equivalent. The value of $\Phi$ parameter for a given cycle duration $t_{c}$ may be calculated with the use of the following equation [12]:

$$
\Phi=\frac{\mathrm{E}}{\mathrm{L}_{\mathrm{n}} \cdot \mathrm{m}}
$$

where: $\mathrm{E}$ - mechanical energy delivered by powertrain system to the wheels, $L_{n}$ - distance covered by the car in the drive mode, $\mathrm{m}$ - gross vehicle mass.

Previous studies $[10,11,12]$ have shown that there is a strong correlation between the operating fuel consumption in the drive mode $\left(\mathrm{Q}_{\mathrm{n}}\right)$ and the specific tractive energy $(\Phi)$ for complex traffic conditions in the city. This correlation can be approximated as a linear function:

$$
\mathrm{Q}_{\mathrm{n}}=\mathrm{k}_{1} \cdot \Phi+\mathrm{k}_{0}
$$

where: $\mathrm{Q}_{n}$ - operating fuel consumption in the drive mode (excluding fuel consumed by the engine at idling), $\mathrm{k}_{1}, \mathrm{k}_{0}$ approximating function coefficients.

This linear function can be used for forecasting operating fuel consumption with great accuracy during vehicle operation in urban conditions. In extra urban conditions, due to extremely favorable conditions of engine operation, the results obtained using the function (4) may be burdened with certain systematic error (small load variability and, as far as efficiency is concerned, a favorable position of engine operating point $[6,9,15])$. The function (4) for the vehicle in question can be calculated using only one drive in regular traffic conditions [12].

Figures 11 and 12 show the influence of specific tractive energy $(\Phi)$ on operating fuel consumption in the drive mode $\left(Q_{n}\right)$ for the vehicle equipped with the diesel engine or the gasoline engine (Tab. 1), respectively. The data were calculated on the basis of simulations with the use of the mathematical model (Fig. 1) for traffic conditions recorded for a passenger car during road tests conducted in real city

\section{Identyfikacja warunków eksploatacji pojazdu $z$ wykorzystaniem energochłonności jednostkowej}

Warunki eksploatacji pojazdu mogą być jednoznacznie identyfikowane za pomocą liczbowego wskaźnika energetycznego, zwanego energochłonnością jednostkową $\Phi$, który obejmuje zarówno wpływ warunków zewnętrznych, jak również styl jazdy kierowcy $[11,12,15]$. Wymienione czynniki wpływają na ilość energii mechanicznej przekazywanej kołom napędowym i są traktowane jako równoważne. Wartość parametru $\Phi$ dla założonego czasu trwania cyklu tc można obliczyć, korzystając z równania (3) [12], gdzie: E energia mechaniczna dostarczona przez układ przeniesienia napędu do kół, $\mathrm{L}_{\mathrm{n}}$ - droga przejechana przez pojazd w fazie napędzania przez silnik, $\mathrm{m}$ - masa całkowita pojazdu.

Wcześniejsze badania $[10,11,12]$ wykazały, że istnieje ścisła korelacja między przebiegowym zużyciem paliwa $\mathrm{w}$ fazie napędowej $\left(Q_{n}\right)$ a energochłonnością jednostkową $(\Phi)$ dla złożonych warunków ruchu występujących w mieście. Zależność taka może być aproksymowana funkcją liniową (4), gdzie: $Q_{n}$ - przebiegowe zużycie paliwa w fazie napędowej (z wyłączeniem paliwa zużywanego przez silnik na biegu jałowym), $\mathrm{k}_{1}, \mathrm{k}_{0}$ - współczynniki funkcji aproksymującej.

Uzyskana zależność (4) może być stosowana przy zachowaniu dużej dokładności do prognozowania przebiegowego zużycia paliwa przy eksploatacji pojazdu w warunkach miejskich. W warunkach pozamiejskich, ze względu na wyjątkowo korzystne warunki pracy silnika, wyniki uzyskane z zależności (4) mogą być obarczone pewnym systematycznym błędem (mała zmienność obciążenia oraz korzystne, $\mathrm{z}$ punktu widzenia sprawności, położenie punktu pracy silnika $[6,9,15])$. Zależność (4) dla rozważanego pojazdu można wyznaczyć, wykorzystując do tego celu jeden przejazd w warunkach normalnej eksploatacji pojazdu [12].

Na rysunkach 11 i 12 przedstawiono wpływ energochłonności jednostkowej $(\Phi)$ na przebiegowe zużycie paliwa w fazie napędowej $\left(\mathrm{Q}_{\mathrm{n}}\right)$ pojazdu wyposażonego odpowiednio w silnik ZS i ZI (tab. 2). Dane uzyskano na podstawie badań symulacyjnych z użyciem matematycznego modelu (rys. 2) dla warunków ruchu zarejestrowanych podczas badań drogowych pojazdu osobowego w rzeczywistym ruchu miejskim na terenie Gdańska [12].

Wykorzystując zależność (4), można obliczyć prognozowane przebiegowe zużycie paliwa $\mathrm{w}$ fazie napędowej dla założonych warunków pracy pojazdu (na podstawie przebiegu prędkości w czasie i zmian wysokości) $[10,12]$. Przy obliczeniu całkowitego przebiegowego zużycia paliwa pojazdu należy dodatkowo uwzględnić objętość paliwa zużytego przez silnik podczas pracy na biegu jałowym [10, 12]. W tabeli 3 przedstawiono porównanie przebiegowego zużycia paliwa dla założonych warunków ruchu pojazdu (rys. $4-8$ ) wyznaczonego podczas badań symulacyjnych pojazdu oraz z użyciem zależności (4).

Uzyskane rezultaty (tab. 3) pozwalają stwierdzić dobrą zgodność wyników symulacji pracy układu napędowego z wynikami obliczeń z użyciem zależności (4). Maksymalny bezwzględny błąd odwzorowania przebiegowego zużycia 


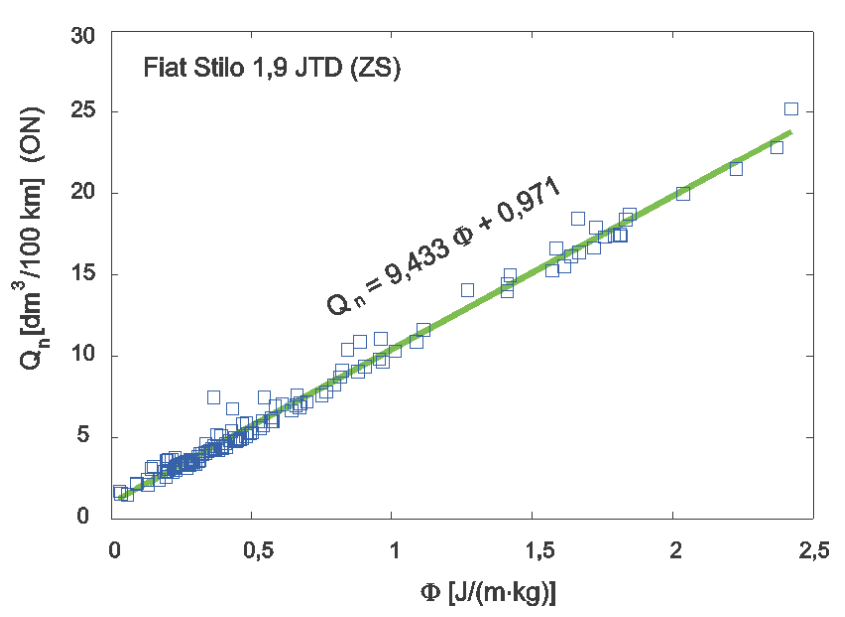

Fig. 11. Influence of the specific tractive energy on operating fuel consumption in drive mode (CI engine)

Rys. 11. Wplyw energochtonności jednostkowej na przebiegowe zużycie paliwa w fazie napędowej (silnik ZS)

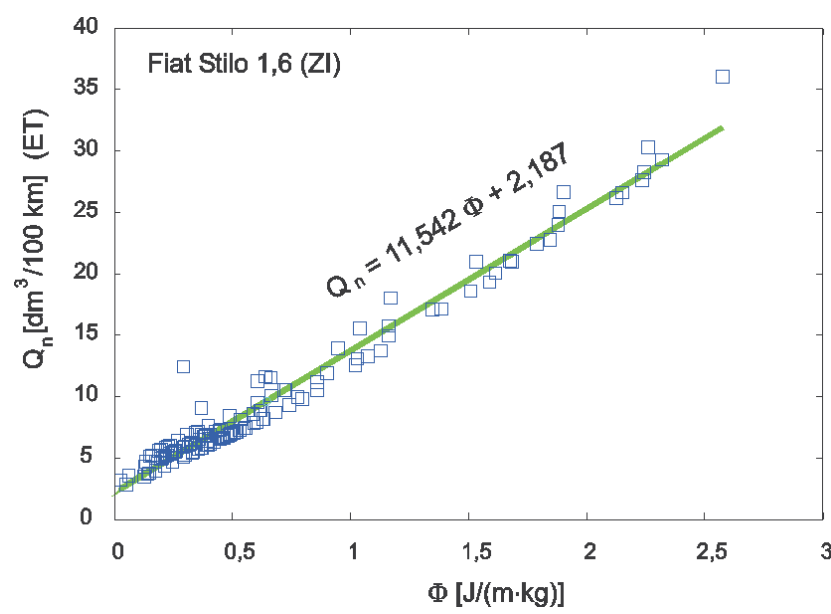

Fig. 12. Influence of the specific tractive energy on operating fuel consumption in drive mode (SI engine)

Rys. 12. Wplyw energochłonności jednostkowej na przebiegowe zużycie paliwa $w$ fazie napędowej (silnik ZI) traffic in the city of Gdansk [12].

On the basis of the speed data and elevation changes the forecasted operating fuel consumption in drive mode for the assumed conditions can be calculated with the use of the function (4) $[10,12]$. When calculating the total operating fuel consumption the amount of fuel consumed by the engine during idling must also be taken into account $[10,12]$. The comparison of operating fuel consumption for given traffic conditions (Fig. $4-8$ ) calculated in simulation tests and calculated with the use of the function (4) has been presented in Tab. 3 .

On the basis of the obtained results (Tab. 3) it can be concluded that simulation tests results tally well enough with the results of calculations made with the use of the function (4). The maximum absolute error of projection of operating fuel consumption was found for the driving on highway and it was $0.9 \mathrm{dm}^{3} / 100 \mathrm{~km}$.

\section{Comparison of energy efficiency of vehicles}

Previous papers $[10,11,12]$ presented the idea of comparing energy efficiency of vehicles powered by the same kind of fuel. In the general case, such a comparison can be done by the coefficients $\mathrm{k}_{1}$ and $\mathrm{k}_{0}$, which define the relative positions of the approximation straights (4) calculated for the considered vehicle. The function (4) for the vehicle equipped with a more efficient powertrain system will be located within the lower range of the fuel consumption in the drive mode. In the case of vehicles powered by different fuels it is reasonable to compare the operating energy supplied to the engine in the fuels due to their different calorific values. The function (4) can then be transformed into the following form: paliwa stwierdzono dla warunków jazdy poza miastem i wyniósł on $0,9 \mathrm{dm}^{3} / 100 \mathrm{~km}$.

\section{Porównywanie efektywności energetycznej pojazdów}

We wcześniejszych pracach $[10,11,12]$ przedstawiono koncepcję porównywania efektywności energetycznej pojazdów zasilanych tym samym rodzajem paliwa. Ogólnie takie porównanie można przeprowadzić za pomocą współczynników $\mathrm{k}_{1}$ i $\mathrm{k}_{0}$ określających wzajemne położenie prostych aproksymacyjnych (4) utworzonych dla rozważanych pojazdów. Przebieg funkcji (4) utworzonej dla pojazdu o bardziej efektywnym układzie napędowym będzie położony w zakresie niższego przebiegowego zużycia paliwa w fazie napędowej. Dla pojazdów zasilanych różnymi paliwami zasadne jest porównywanie przebiegowego zużycia energii dostarczonej w paliwie w fazie napędowej ze względu na różną wartość opałową jednostki objętości paliwa. Zależność 


$$
\mathrm{E}_{\mathrm{n}}=\left(\mathrm{k}_{1} \cdot \Phi+\mathrm{k}_{0}\right) \cdot \rho_{\mathrm{pal}} \cdot \mathrm{W}_{\mathrm{d}}
$$

where: $\mathrm{E}_{\mathrm{n}}$ - operating energy released from fuel in the drive mode (excluding energy released from fuel at idling), $\mathrm{W}_{\mathrm{d}}-$ fuel calorific value.

A comparison of energy efficiency of such vehicles can then be made using the equation (5) established for the compared vehicles. The approximation straight line of equation (5) for the vehicle with a more efficient powertrain system will be located in the lower range of the operating energy released from the fuel in drive mode.

A comparison of energy efficiency of vehicles can also be made with the use of the following parameter for the adopted range of the specific tractive energy:

$$
\overline{\mathrm{E}}_{\mathrm{n}}=\frac{1}{2}\left(\left.\mathrm{E}_{\mathrm{n}}\right|_{\Phi_{\min }}+\left.\mathrm{E}_{\mathrm{n}}\right|_{\Phi_{\max }}\right)
$$

where: $\left.E_{n}\right|_{\Phi_{\text {min }}}$ - operating energy released from fuel in drive mode for $\Phi=\Phi_{\min },\left.E_{n}\right|_{\Phi_{\max }}$ - operating energy released from fuel in drive mode for $\Phi=\Phi_{\text {max }}$.

In the case of a vehicle with a more efficient powertrain system the value of the parameter (6) will be smaller. Assuming that $\Phi_{\min }=0.1$ and $\Phi_{\max }=2.0$, values of the parameter (6) have been calculated for the tested vehicles. On the basis of the obtained results it was concluded that the vehicle powered by diesel fuel $(431 \mathrm{MJ} / 100 \mathrm{~km})$ is more energy efficient than the vehicle powered by gasoline $(388 \mathrm{MJ} / 100 \mathrm{~km})$.

\section{Conclusions}

Comparing operating fuel consumption in the conditions of a selected certification test is the most popular method of assessing energy efficiency of vehicles. Operating conditions which are defined by the speed profiles, are usually specified for only two categories: urban and extra-urban driving. Problems arising from such a practice have been discussed with the use of the analysis of operating fuel consumption and operating energy released from fuel calculated for selected traffic conditions in Gdansk and in its suburbs for vehicles with a diesel engine and a gasoline engine. On the basis of the obtained results it was concluded that the vehicle powered by the SI engine consumes more operating energy from fuel than the vehicle powered by the CI engine in each analyzed case. Depending on the driving style, the current traffic problems and the average velocity, those differences in the energy consumption change within a relatively wide range $(1-18) \%$. Therefore, the comparison of energy efficiency of vehicles powered by different fuels should be performed using a more detailed classification of conditions than a simple division between urban and extra urban driving.

The new method of assessing energy efficiency of vehicles powered by different fuels presented in the paper allows for performing analyses based on a single drive in regular city traffic when the basic parameters of the engine and of the vehicle are recorded. When comparing energy efficiency vehicles
(4) można wówczas przekształcić do postaci (5), gdzie: $\mathrm{E}_{\mathrm{n}}$ - przebiegowe zużycie energii dostarczonej w paliwie $\mathrm{w}$ fazie napędowej ( $\mathrm{z}$ wyłączeniem energii dostarczanej w postaci paliwa podczas pracy silnika na biegu jałowym), $\mathrm{W}_{\mathrm{d}}$ - wartość opałowa paliwa.

Porównanie efektywności energetycznej takich pojazdów można wówczas wykonać za pomocą zależności (5) utworzonych dla porównywanych pojazdów (rys. 13). Przebieg zależności (5) pojazdu o bardziej efektywnym układzie napędowym będzie znajdował się w zakresie niższego przebiegowego zużycia energii w fazie napędowej.

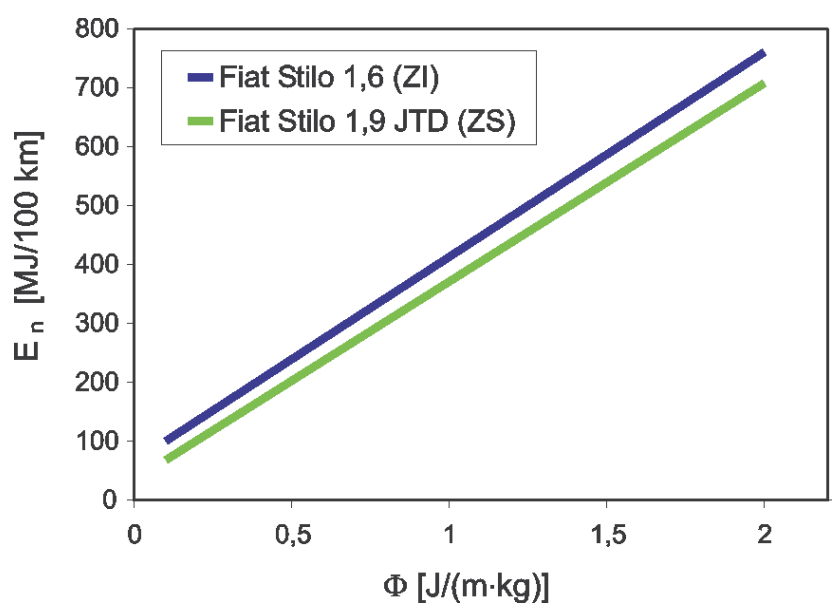

Fig. 13. Relative position of approximation straight lines (5), which have been obtained for CI and SI engine

Rys. 13. Wzajemne położenie prostych aproksymacyjnych (5) uzyskanych dla silnika ZS i ZI

Porównanie efektywności energetycznej pojazdów można również przeprowadzić, posługując się wartością średnią przebiegowego zużycia energii w fazie napędowej dla przyjętego zakresu zmian parametru $\Phi$-wzór (6), gdzie: $\left.\mathrm{E}_{\mathrm{n}}\right|_{\Phi_{\text {min }}}$

- przebiegowe zużycie energii w fazie napędowej wyznaczone dla $\Phi=\Phi_{\min },\left.\mathrm{E}_{\mathrm{n}}\right|_{\Phi_{\max }}$ - przebiegowe zużycie energii w fazie napędowej wyznaczone dla $\Phi=\Phi_{\max }$.

Dla pojazdu z efektywniejszym układem napędowym wartość przebiegowego zużycia energii w fazie napędowej będzie mniejsza. Przyjmując, że oraz , wyznaczono wartość wskaźnika (6) dla pojazdu wyposażonego odpowiednio w silnik ZS i ZI. Na podstawie uzyskanych wyników stwierdzono, że bardziej efektywny energetycznie jest pojazd z silnikiem ZS (431 MJ/100 km) niż z silnikiem ZI (388 MJ/100 km).

\section{Wnioski}

Najpopularniejsza metoda oceny efektywności energetycznej pojazdów samochodowych polega na porównywaniu przebiegowego zużycia paliwa osiągniętego w warunkach wybranego testu homologacyjnego. Warunki eksploatacji, zdefiniowane za pomocą przebiegów prędkości w czasie, dotyczą najczęściej tylko dwóch kategorii: jazdy miejskiej 
the first step is to express the relation between operating fuel consumption in drive mode and the specific tractive energy in the form of the equation (4). Then the relation between the consumption of the operating energy from fuel in drive mode and the specific tractive energy needs to be expressed by the equation (5). The obtained equations allow for forecasting operating fuel consumption or the consumption of the operating energy released from fuel in the drive mode for given operating conditions. The quantitative comparison of energy efficiency of vehicles can then be performed using the parameter (6). The method proposed in the present paper allows for a more reliable comparison of energy efficiency of vehicles than is the case when operating fuel consumption in a selected certification test is compared.

Paper reviewed/Artykut recenzowany

\section{Bibliography/Literatura}

[1] Alvarez R., Weilenmann M., Bach Ch.: Potential of natural gas powered vehicles in reducing $\mathrm{CO}_{2}$ and pollutant emissions under real-world driving conditions. FISITA 2010 World Automotive Congress, Budapest 2010, F2010-A-035.

[2] Cayot J.F.: Compared fuel consumption between gasoline and diesel cars during short urban drive. Reducing automobile fuel consumption: a challenge for the turn of the century, RueilMalmaison 1996.

[3] Chłopek Z.: Ochrona środowiska naturalnego. WKit, Warszawa 2002.

[4] Cichy M., Kropiwnicki J., Makowski S.: Model silnika spalinowego w formie grafów wiązań $(\mathrm{GW})$. Silniki Spalinowe nr 2, 2004, s. 40-47.

[5] Cichy M.: Modelowanie systemów energetycznych. Wydawnictwo Politechniki Gdańskiej, Gdańsk 2001.

[6] Combe T., Kollreider A., Riel A., Schyr Ch.: Modellabbildung des Antriebsstrangs-Echtzeitsimulation der Fahrzeuglaengsdynamik. MTZ 1/2005, s. 50-59.

[7] Gao Y., Checkel M.D.: Experimental measurement of on-road $\mathrm{CO}_{2}$ emission and fuel consumption functions. SAE Technical Paper Series, 2007-01-1610.

[8] Kawai T.: Fuel Consumption Test Protocol Concept for Plug-in Hybrid Electric Vehicle. SAE Technical Paper Series, 200901-1839.

[9] Kretzsch M., Günther M., Elsner N., Zwahr S.: Modellansätze für die virtuelle Applikation von Motorsteuergeräten. MTZ 09/2009: 665-670.

[10] Kropiwnicki J.: Estimation of vehicle operational fuel consumption. Combustion Engines nr 3, 2010.

[11] Kropiwnicki J.: Koncepcja nowego testu energetycznego dla pojazdów samochodowych. Archiwum Motoryzacji nr 2, 2007, s. $169-183$.

[12] Kropiwnicki J.: Ocena efektywności energetycznej pojazdów samochodowych z silnikami spalinowymi. Wydawnictwo Politechniki Gdańskiej. Seria Monografie nr 110, Gdańsk 2011, s. $1-115$.

[13] Merkisz J., Pielecha J., Gis W.: Investigations on vehicle exhaust emissions under real road conditions. Combustion Engines, 2009-SC1, Powertrain, Design, Ecology\&Diagnostics, 2009, s. 43-53.

[14] Patil R., Filipi Z. S., Adornato B.: Impact of naturalistic driving patterns on PHEV performance and system design. SAE Technical Paper Series, 2009-01-2715. i pozamiejskiej. Problemy wynikające z takiego sposobu postępowania omówiono na przykładzie analizy przebiegowego zużycia paliwa w wybranych warunkach ruchu pojazdów na terenie Gdańska i okolic.

W pracy przedstawiono analizę wpływu warunków eksploatacji, zdefiniowanych za pomocą przebiegów prędkości pojazdu w czasie, na przebiegowe zużycie paliwa. Uzyskane wyniki pozwoliły stwierdzić, że pojazd z silnikiem ZI zużywa w każdym analizowanym przypadku więcej energii zawartej w paliwie niż z silnikiem ZS. Różnica ta zmienia się w szerokim zakresie: $(1-18) \%$, przy czym różnice te są mniejsze dla warunków, które można sklasyfikować jako jazda pozamiejska i większe dla warunków miejskich. Można więc wnioskować, że porównanie efektywności energetycznej pojazdów samochodowych zasilanych różnymi paliwami powinno być wykonywane przy użyciu bardziej szczegółowej klasyfikacji warunków niż prosty podział na jazdę miejską i pozamiejską.

Przedstawiona nowa metoda porównywania efektywności energetycznej pojazdów zasilanych różnymi paliwami umożliwia wykonanie analizy na podstawie jednego przejaz$\mathrm{du} \mathrm{w}$ warunkach regularnego ruchu miejskiego z rejestracją podstawowych parametrów pracy silnika i pojazdu. W pierwszym etapie porównywania efektywności energetycznej pojazdów konieczne jest utworzenie dla każdego z badanych pojazdów zależności między przebiegowym zużyciem paliwa w fazie napędowej a energochłonnością jednostkową (4), a następnie zależności między przebiegowym zużyciem energii w fazie napędowej a energochłonnością jednostkową (5). Uzyskane w ten sposób zależności umożliwiają prognozowanie przebiegowego zużycia paliwa lub energii w niej zawartej dla zadanych warunków eksploatacji. Ilościowe porównanie efektywności energetycznej pojazdów można następnie przeprowadzić, posługując się zaproponowanym w pracy wskaźnikiem (6). Zaproponowana w pracy metoda umożliwia porównywanie efektywności energetycznej układów napędowych różnych pojazdów w sposób bardziej miarodajny niż jest to czynione obecnie - porównywanie przebiegowego zużycia paliwa osiągniętego w warunkach wybranego testu homologacyjnego.

[15] Siłka W.: Energochłonność ruchu samochodu. WNT, Warszawa 1997.

[16] Tzirakis E., Pitsas K., Zannikos F., Stournas S.: Vehicle emissions and driving cycles: comparison of the Athens Driving Cycle (ADC) with ECE-15 and European Driving Cycle (EDC). Global NEST Journal, Vol. 8, No. 3, 2006, s. 282290.

Jacek Kropiwnicki, DEng. - doctor in the Faculty of Mechanical Engineering at Gdańsk University of Technology.

Dr inż. Jacek Kropiwnicki - adiunkt na Wydziale Mechanicznym Politechniki Gdańskiej. e-mail:jkropiwn@sunrise.pg.gda.pl 